\title{
Effectiveness of Stenting as Bridge to Surgery in Left Sided Malignant Obstructions; Single Center Results
}

\section{Sol Taraflı Malign Obstrüksiyonlarda Köprüleme Tedavisi Olarak Stent Yerleştirmenin Etkinliği; Tek Merkez Analiz Sonuçları}

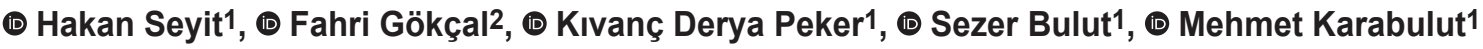 \\ ${ }^{1}$ Bakırköy Dr. Sadi Konuk Training and Research Hospital, Clinic of General Surgery, İstanbul, Turkey \\ ${ }^{2}$ Good Samaritan Medical Center, Tufts University School of Medicine, Brockton, MA, USA
}

\section{HIIIIII| ABSTRACT}

\begin{abstract}
Aim: Intestinal obstruction due to colorectal cancer should be urgently decompressed due to high morbidity. Its treatment includes palliative interventions, emergency laparotomy and bridge to surgery. In this study, we aimed to evaluate the effects of stenting on surgical and oncological outcomes by comparing it with the emergency surgery.

Method: Patients admitted between January 2019 and February 2020 due to acute malignant left-sided colon obstruction were analyzed. The groups who underwent emergency laparotomy (group E) and those who underwent elective surgery after stenting (group S) were compared. Demographic and preoperative basic characteristics, early postoperative outcomes and mortality rates of the patients were examined.

Results: Forty-six patients, 20 in the stenting group (group S) and 26 in the emergency surgery group (group E) were included in the study. Age, gender, tumor location, ASA status and $\mathrm{N}$ stage of the groups were similar. The T stages were significantly higher in the group $\mathrm{E}$ (p<0.01). While technical success was achieved in 17 patients (85.0\%) and clinical success in 14 patients (70.0\%) in the group S, emergency laparotomy was performed in 6 patients. In 7 patients (35.0\%) in group S, the surgery was completed laparoscopically. The groups were similar in terms of permanent stoma, length of stay, and 30-day mortality rates, while significantly lower complications were observed in the stenting group ( $15 \%$ vs $50 \%$, $\mathrm{p}=0.013$ ). Conclusion: Elective laparoscopic colectomy after stent decompression may be possible with less severe morbidity and lower 30 day mortality in the management of acute left-sided colon obstruction.
\end{abstract}

Keywords: Malignant obstruction, colonic stenting, bridge to surgery, laparoscopic resection

\section{|IIIIIIII| ÖZ}

Amaç: Kolorektal kansere bağlı bağırsak tıkanıklığı yüksek morbidite nedeniyle acil dekomprese edilmelidir. Tedavisi palyatif girişimler, acil laparotomi ve köprüleme tedavisidir. Bu çalışamada stent yerleştirmenin cerrahi ve onkolojik sonuçlar üzerindeki etkilerini acil cerrahi grubu ile karşılaştırarak değerlendirmeyi amaçladık.

Yöntem: Akut malign sol taraflı kolon tıkanıklık nedeniyle Ocak 2019 ile Şubat 2020 tarihleri arasında müracaat eden hastalar analiz edildi. Acil laparotomi (grup E) yapılanlar ile stentleme sonrası elektif ameliyat edilen (grup S) gruplar karşılaştırıldı. Hastaların demografik ve ameliyat öncesi temel özellikleri, erken postoperatif sonuçları ve mortalite oranları incelendi.

Bulgular: Stent grubunda (grup S) 20 ve acil cerrahi grubunda (grup E) 26 olmak üzere 46 hasta çalışmaya dahil edildi. Grupların; yaş, cinsiyet, tümör yerleşimi, ASA durumu ve N evresi benzerdi. Acil laparatomi grubunda T evre oranı anlamlı düzeyde yüksekti ( $\mathrm{p}<0,01)$. Stent grubundaki 17 hastada $(\% 85,0)$ teknik ve 14 hastada $(\% 70,0)$ klinik başarı sağlanırken 6 hastaya acil laparotomi yapıldı. Grup S'de 7 hastaya (\%35,0) ameliyat laparoskopik tamamlandı. Gruplar; kalıcı stoma, yatış süresi ve 30 günlük mortalite oranları açısından benzerken, stentleme grubunda anlamlı derecede düşük düzeyde komplikasyon görüldü (\%15’e karşı \%50, p=0,013).

Sonuç: Akut sol taraflı kolon tıkanıklığının tedavisinde stent ile dekompresyonundan sonra elektif laparoskopik kolektomi daha az ciddi morbidite ve daha düşük 30 günlük mortalite ile mümkün olabilir.

Anahtar Kelimeler: Malign obstrüksiyon, kolonik stentleme, köprüleme tedavi, laparoskopik rezeksiyon

Address for Correspondence/Yazışma Adresi: Hakan Seyit, MD,

Bakırköy Dr. Sadi Konuk Training and Research Hospital, Clinic of General Surgery, İstanbul, Turkey

Phone: +90 5058242737 E-mail: hakanseyi@@gmail.com ORCID ID: orcid.org/0000-0003-3708-5370

Received/Gelis Tarihi: 07.04.2020 Accepted/Kabul Tarihi: 14.05.2020

${ }^{\odot}$ Copyright 2020 by Turkish Society of Colon and Rectal Surgery

Turkish Journal of Colorectal Disease published by Galenos Publishing House. 


\section{Introduction}

Colorectal cancer is one of the most common cancers affecting the population and often causes symptoms with acute obstruction findings. Intestinal obstruction due to colorectal cancer should be urgently decompressed due to colonic distension, bacterial translocation and the risk of colon necrosis and perforation as a result of electrolyte and fluid imbalance. While approximately $80 \%$ of emergency colon surgeries were performed due to obstruction, ${ }^{1}$ emergency laparotomy with low primary anastomosis and high morbidity rates was classically involved in the treatment of obstruction. ${ }^{2}$ In a study of 1,046 patients presenting with malignant bowel obstruction, $24.3 \%$ of the patients were treated with Hartmann's procedure or palliative stoma. ${ }^{3}$ Of Hartmann procedures for left-sided malignant obstructions, $40 \%$ are not closed. ${ }^{4}$

Dohmoto et $a .^{5}$ defined the stenting technique for the palliative treatment of colorectal tumors causing stenosis in 1990. It has been stated that the main advantage of stenting is to transform an emergency surgery into an elective surgery as a result of colonic decompression, thereby reducing morbidity and mortality. ${ }^{6}$ However, the benefits of endoscopic stenting both for palliation and as a bridge to elective surgery are controversial, as some studies published on this topic have shown conflicting results. Van Hooft et al. ${ }^{7}$ reported in a randomized controlled study that the high colonic perforation rate in the stenting group caused more septic complications and an increase in 30 day mortality. In addition, the perforation caused by the stent is thought to cause the spread of tumor cells and therefore worse longterm oncological outcomes. ${ }^{8}$

The aim of this study was to evaluate the effects of stenting on surgical and oncological outcomes in patients with obstruction due to colorectal cancer by comparing with the emergency surgery.

\section{Materials and Methods}

Patients admitted to our hospital with acute malignant leftsided colon obstruction between January 2019 and February 2020 were analyzed retrospectively from a prospectively managed database. Patients with colon obstruction due to tumor between splenic flexure and rectosigmoid region were included. Patients with peritonitis, suspected ischemia on computed tomography (CT) scan, recurrent colorectal cancer, or evidence of diffuse disease were excluded.

In our endoscopy unit, stenting was performed by experienced endoscopists under fluoroscopy. A metal stent in the range of 8-12 cm (CHANGZHOU ZHIYE MEDICAL DEVICES INSTITUTE, No.127 xiaCheng Road, Wujin High-tech Industrial Development Zone, Changzhou) was placed using the images taken during contrast-enhanced CT and fluoroscopy. The technical success of stenting was assessed by spontaneous liquid stool discharge and stent patency confirmed by contrast agent administration (Figure 1). A routine abdominal X-ray was performed 24 hours after the procedure. Clinical success was defined as the regression of obstructive symptoms within 72 hours after the procedure with stool passage. ${ }^{7}$ Patients with regression of obstruction findings underwent optimization of their medical conditions, including CT scanning of the chest, abdomen and pelvis, and extensive oncological study, if not performed prior to stenting.

Colectomy was performed by first trying the laparoscopic approach in all patients with clinical success in bowel decompression. If surgeons doubted the integrity and safety of the anastomosis during the peroperative period,
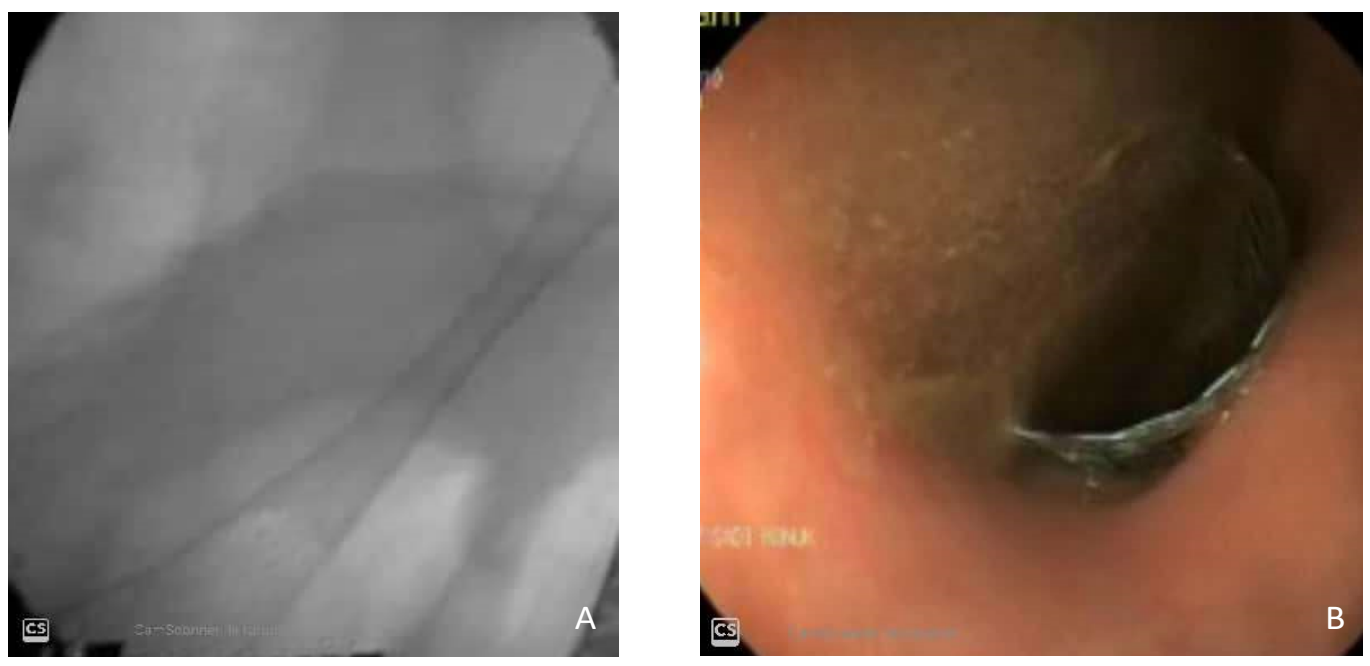

Figure 1. Confirmation of stent patency by fluoroscopy and colonoscopy (A: Fluoroscopy view, B: Colonoscopy view) 
a diverting stoma was created. Emergency laparotomy was performed in patients with clinical failure, in whom stent could not be placed, or in whom complications developed after stenting.

Emergency laparotomy was performed, especially in the weekend conditions, when fluoroscopy was not available, or in patients who refused stenting. The surgical technique was determined due to the patient's clinical condition and the surgeon's decision. In the postoperative period, all patients were referred to a clinical oncologist for management of adjuvant chemotherapy. Demographic findings, ASA status, location of tumor, pathological features, technical and clinical success results of stenting, diverting stoma, hospital stay, postoperative complications and mortality data were prospectively recorded and retrospectively collected for all patients included in the study. Length of stay in hospital was defined as the total number of days spent in the hospital after surgery. Operative mortality was defined as deaths occurring within 30 days postoperatively. Anastomotic leak was defined as clinical or radiological evidence of leakage from the anastomosis.

The study was exempted from review by our hospital's ethics committee, as it was a retrospective case series presenting our center's clinical and oncological outcomes of colonic stenting which was bridge to surgery.

\section{Statistical Analysis}

Number Cruncher Statistical System (NCSS) 2007 Statistical Software (Utah, USA) program was used for statistical analysis. While evaluating the study data, in addition to descriptive statistical methods (mean, standard deviation, median, frequency, ratio), Shapiro Wilk test and boxplot graphics were used when variables had normal distribution.

Table 1. Demographic and basic characteristics of the patients

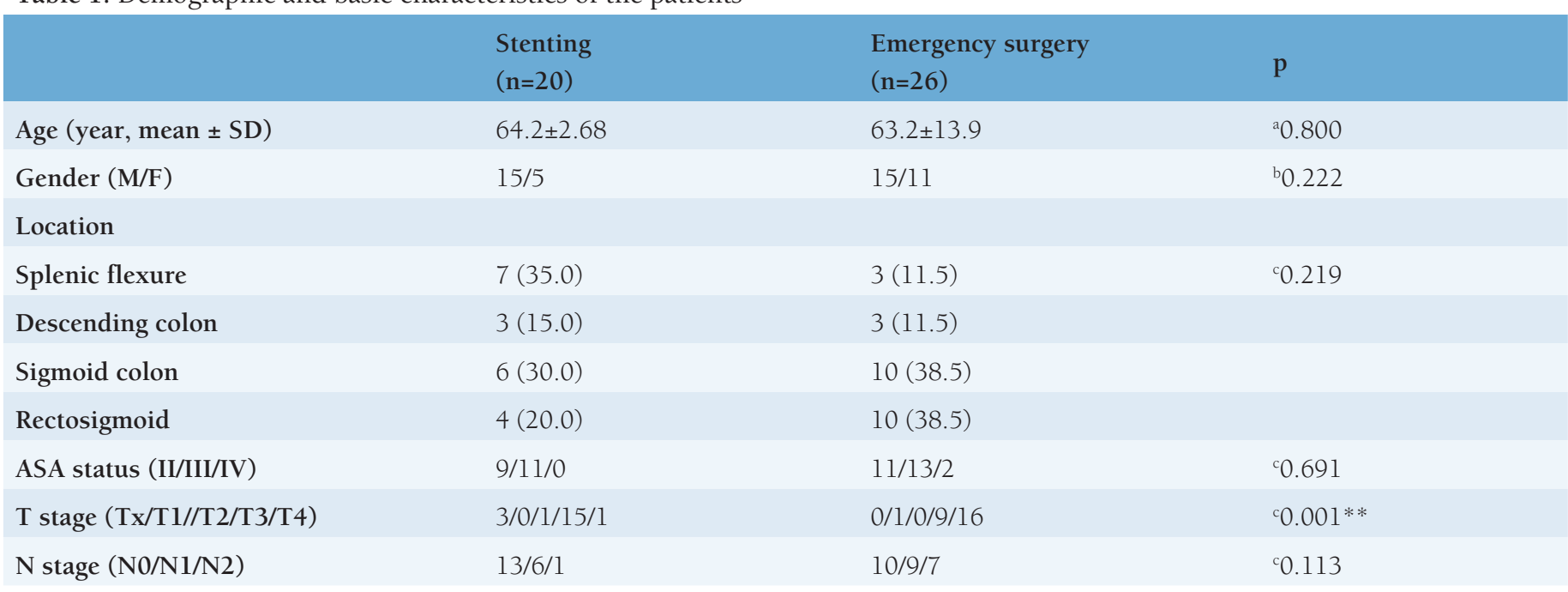

Student t-test was used to compare variables with normal distribution between groups, and Mann Whitney U test was used to compare variables without normal distribution between groups. For comparison of qualitative data, chisquare test, Fisher's exact test and Fisher-Freeman Halton test were used. $\mathrm{P}$ value $<0.05$ was accepted statistically significant.

\section{Results}

Between January 2019 and February 2020, 20 patients in the group $S$ and 26 patients in the group E (a total of 46 patients) were included in the study. There was no difference between the two groups in terms of age, gender, tumor location, ASA status, and $\mathrm{N}$ stage (Table 1). There was a significant difference between the groups in terms of $\mathrm{T}$ stage $(\mathrm{p}<0.01)$. In group $\mathrm{E}$, the rate of advanced stages was significantly higher (Figure 2).

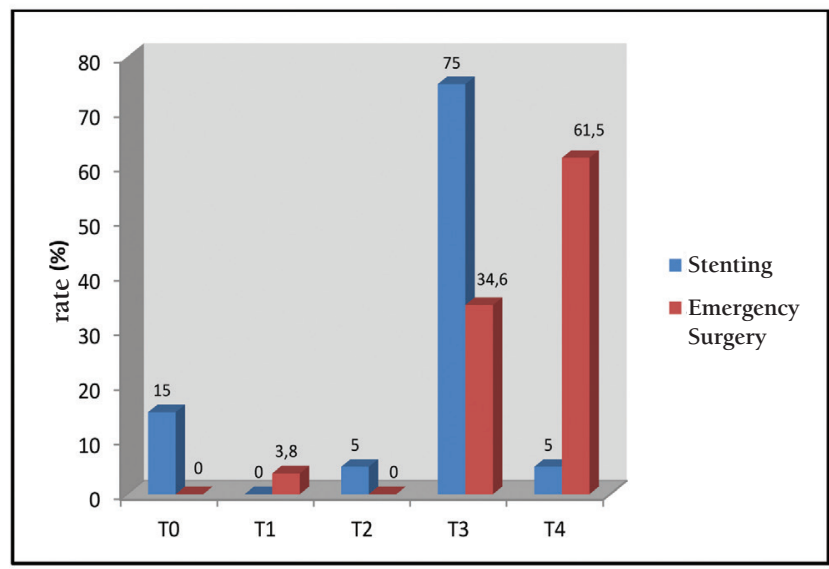

Figure 2. Distribution of $\mathrm{T}$ stage by groups

SD: Standard deviation, M: Male, F: Female 
Technical success was achieved in 17 patients (85.0\%) in the stenting group. Technical failure occurred in 3 patients, as the guide wire could not pass proximal of tumor due to complete obstruction. T stages were accepted as Tx, since loop colostomy without resection was performed in these patients with emergency laparotomy. Clinical success was achieved in 14 patients (70.0\%). While migration was observed in the abdominal X-ray of 1 patient with persistent bowel obstruction symptoms, perforation was observed in 3 patients, ongoing ileus was observed in 2 patients, and emergency laparotomy was performed in those patients. Laparoscopic resection was completed in 7 patients (35.0\%) in the stenting group. Emergency surgeries were performed in patients with technical failure or clinical failure.

The diverting stoma rates did not differ significantly between the groups (5\% in the stenting group and $11.5 \%$ in the emergency surgery group, $\mathrm{p}=0.622$ ). The duration of hospital stay was similar between the two groups ( 6 and 7.5 days in the group $\mathrm{S}$ and $\mathrm{E}$, respectively). Complications were graded according to Clavien-Dindo classification ${ }^{9}$. The total number of complications was significantly higher in the emergency surgery group and lower in the stenting group ( $15 \%$ vs $50 \%, \mathrm{p}=0.013$ ) (Figure 3 ). There was no significant difference between the groups in terms of the 30day mortality rates ( $5 \%$ vs $11.5 \%, \mathrm{p}=0.622$ ) (Table 2 ).

\section{Discussion}

Left-sided colorectal tumors can emerge as an emergency resulting in large bowel obstruction, bacterial translocation, electrolyte and fluid imbalance. For this reason, the main goals of the treatment are to remove the obstruction, resection of the obstructive pathology, and maintain the intestinal continuity. Although gradual operation with resection and colostomy is often performed, onestage procedure (resection and primary anastomosis) has become increasingly popular. Despite advances in surgical techniques and perioperative care, there are high morbidity and mortality rates in emergency surgery. ${ }^{10,11}$ Therefore, the role of colorectal stenting as a bridge to both palliation and elective surgery has been widely discussed, despite several studies reporting conflicting results. Although some publications claim that the colonic stenting is harmful and can cause the spread of cancer secondary to tumor perforation $^{12}$ a meta-analysis has been reported showing that the oncologic results are acceptable and safe..$^{13}$

In fact, stenting is often difficult in patients with total obstruction or narrow-angle tumors in relation to the lumen. These are also identified as risk factors for stentrelated complications. ${ }^{14}$ Similar to a recently reported meta-analysis, a technical success rate of $95.2 \%$ has been reported for stenting. ${ }^{15}$ This procedure performed in low-volume centers and by endoscopists who are not experienced in invasive techniques such as endoscopic retrograde cholangiopancreatography has been shown to be related with higher technical failure and complication rates, particularly with respect to procedure-related perforations. ${ }^{16}$ Colorectal stenting may be associated with complications in $5-20 \%$ of patients. ${ }^{17}$ Therefore, the surgeon's familiarity with the stenting system is of paramount importance for technical and clinical success. Our clinical success rate (70.0\%) is comparable to the literature, as all procedures performed using the endoscopic method (ERCP, EUS and other endoscopic invasive treatments) are performed in the endoscopy unit of our clinic and our center is a high-volume center. ${ }^{18}$

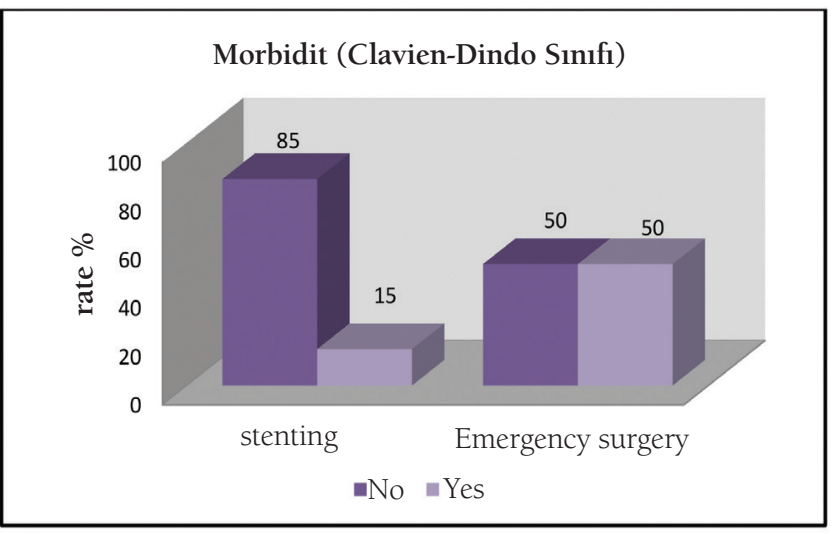

Figure 3. Distribution of morbidity rates by groups

Table 2. Early postoperative results

\begin{tabular}{|c|c|c|c|}
\hline & $\begin{array}{l}\text { Stenting } \\
(\mathrm{n}=20)\end{array}$ & $\begin{array}{l}\text { Emergency surgery } \\
(\mathrm{n}=26)\end{array}$ & $\mathrm{p}$ \\
\hline Diverting stoma n (\%) & $1(5.0)$ & $3(11.5)$ & ${ }^{\mathrm{d}} 0.622$ \\
\hline Primary anastomosis n (\%) & $15(75.0)$ & $17(65.4)$ & b0.482 \\
\hline 30 days of death $\mathbf{n}(\%)$ & $1(5.0)$ & $3(11.5)$ & ${ }^{\mathrm{d}} 0.622$ \\
\hline Morbidity (Clavien-Dindo (1-2/3-4) & $17 / 3$ & $13 / 13$ & b0.013* \\
\hline Length of stay (day), median (IQR) & $6(5-7.8)$ & $7.5(5.8-9.0)$ & ${ }^{\mathrm{e}} 0.056$ \\
\hline
\end{tabular}


First reported as a palliative therapy for unresectable colon tumors, stenting has recently been reported to lend assistance to intestinal decompression for delayed elective resection. ${ }^{19}$ This approach prevents stoma and makes an emergency operation safer after the bowel has been prepared mechanically. The optimal timing for elective surgery after stenting remains controversial. An interval of 2 weeks is recommended for complete decompression of the colon and reduction of tissue edema. This also provides the opportunity to perform a primary anastomosis without creating a stoma by optimizing the patient's nutritional status until surgery. Because creating permanent or temporary stomata has been shown to negatively affect patients' quality of life and psychosocial well-being. ${ }^{20}$ Two studies compared the results of elective open surgery following stenting with the results of emergency surgery without stenting, and showed an increase in the proportion of patients with successful primary anastomosis and a decrease in stoma formation in the stenting group..$^{21,22}$ When the results of our study were evaluated, we performed significantly less stoma in the stenting group compared to the emergency surgery group.

Similarly, minimally invasive colon surgery for colorectal malignancy is widely used in elective surgery. However, laparoscopic surgery is difficult to perform due to the limitation in the field of view as a result of bowel dilatation and the risk of injury is higher. The rate of laparoscopic bowel resection can be increased with decompression after stenting. In this study, laparoscopic colectomy was successfully performed in 7 patients (35\%) with stenting. Although this was lower than the rate reported in a randomized controlled trial conducted by $\mathrm{Cheung}^{23}$, our rate of conversion to open surgery was comparable with the rate of $25 \%$ reported in the MRC CLASSIC trial by Guillou et al. ${ }^{24}$

Emergency surgery for colorectal cancer obstruction is associated with higher morbidity (40-50\%) than elective colorectal surgery. ${ }^{25}$ When our results were evaluated, a difference was found between the two groups in terms of the total morbidity. There were more patients in the emergency surgery group with Clavien-Dindo grade III or IV complications. There was no significant difference between the two groups in terms of the total length of hospital stay. When evaluated in the light of the literature information, laparoscopic surgery has positive results on patient comfort and shortening of hospital stay due to early discharge. ${ }^{23} \mathrm{We}$ think that stent bridging treatment may lead to a decrease in the length of stay and complication rates in the current study, since it allows laparoscopic surgery.

Reported mortality rates for emergency colorectal surgery were higher in previous studies compared to elective surgery. ${ }^{10,11}$ However, a recent randomized controlled trial did not show a significant difference in terms of 30-day mortality and total mortality between the two procedures. ${ }^{26}$ The 30-day mortality rate in our study was comparable to other series in the literature. ${ }^{27}$ It was lower in the stenting group compared to the emergency surgery group $[n=3$ (11.5\%) and $\mathrm{n}=1$ (5.0\%), respectively, $\mathrm{p}=0.622]$.

There were some limitations of our study. Since it was a retrospective comparative study, it was not possible to standardize the patient selection and management protocol. Randomization of the patients was difficult because fluoroscopy was only available during working hours in the endoscopy unit. In addition, all elective colorectal surgeries were performed by colorectal surgeons in our clinic, while emergency colon surgeons were performed by on-duty general surgery specialists. The experience of the two groups of surgeons was different, so depending on the patient factor and surgeon preference, the decision to create a stoma was outside the standards.

\section{Conclusion}

As a result; the use of colonic self-expanding metallic stents as a bridge to surgery is feasible and effective in the treatment of acute left-sided colon obstruction. Less stoma formation is associated with less severe morbidity and lower 30-day mortality. Elective laparoscopic colectomy may be possible after successful colon decompression. We believe that multicenter prospective studies with higher number of patients will help define the role of colonic stenting as a bridge to surgery.

\section{Ethics}

Ethics Committee Approval: The study was exempted from review by our hospital's ethics committee, as it was a retrospective case series presenting our center's clinical and oncological outcomes of colonic stenting which was bridge to surgery.

Informed Consent:

Peer-review: Internally peer reviewed.

\section{Authorship Contributions}

Surgical and Medical Practices: H.S., K.D.P., M.K., Concept: H.S., Design: H.S., Data Collection or Processing: H.S., S.B., Analysis or Interpretation: H.S., F.G., Literature Search: H.S., F.G., S.B., Writing: H.S., F.G., K.D.P., M.K.

Conflict of Interest: No conflict of interest was declared by the authors.

Financial Disclosure: The authors declared that this study received no financial support. 


\section{References}

1. Beksaç K, Üstüner MA, Cetin B. Left-Sided Colonic Obstruction Due to Brid Ileus and Coexisting Right Colon Cancer without Palpable Mass. Turk J Colorectal Dis 2018;28:99-101.

2. Pavlidis TE, Marakis G, Ballas K, Rafailidis S, Psarras K, Pissas D, Sakantamis AK. Does emergency surgery affect resectability of colorectal cancer? Acta Chir Belg 2008;108:219-225

3. Tekkis PP, Kinsman R, Thompson MR, Stamatakis JD, Association of Coloproctology of Great Britain, Ireland. The Association of Coloproctology of Great Britain and Ireland study of large bowel obstruction caused by colorectal cancer. Ann Surg 2004;240:76-81.

4. Deans GT, Krukowski ZH, Irwin ST. Malignant obstruction of the left colon. Br J Surg 1994;81:1270-1276.

5. Dohmoto M, Rupp KD, Hohlbach G. Endoscopically-implanted prosthesis in rectal carcinoma. Dtsch Med Wochenschr 1990;115:915.

6. Zhang Y, Shi J, Shi B, Song CY, Xie WF, Chen YX. Self-expanding metallic stent as a bridge to surgery versus emergency surgery for obstructive colorectal cancer: a meta-analysis. Surg Endosc 2012;26:110-119.

7. Van Hooft JE, Bemelman A, Oldenburg B, Marindlli AW, Holzik MF, Grubben MJ, Sprangers MA, Dijkgraaf MG, Fockens P, collaborative Dutch Stent-In study group. Colonic stenting versus emergency surgery for acute leftsided malignant colonic obstruction: a multicentre randomized trial. Lancet Oncol 2011;12:344-352.

8. Maruthachalam K, Lash GE, Shenton BK, Horgan AF. Tumor cell dissemination following endoscopic stent insertion. Br J Surg 2007;94:1151-1154

9. Dindo D, Demartines N, Clavien PA. Classification of surgical complications-a new proposal with evaluation in a cohort of 6336 patients and results of a survey. Ann Surg 2004;240:205-213.

10. Law WL, Choi HK, Chu KW. Comparison of stenting with emergency surgery as palliative treatment for obstructing primary left-sided colorectal cancer. Br J Surg 2003;90:1429-1433.

11. Smothers L, Hynan L, Fleming J, Turnage R, Simmang C, Anthony T. Emergency surgery for colon carcinoma. Dis Colon Rectum 2003;46:2430.

12. Di Saverio S, Birindelli A, Segalini E, Novello M, Larocca A, Ferrara F, Binda GA, Bassi M. "To stent or not to stent?": immediate emergency surgery with laparoscopic radical colectomy with CME and primary anastomosis is feasible for obstructing left colon carcinoma. Surg Endosc 2018;32:21512155.

13. Amelung FJ, Burghgraef TA, Tanis PJ, van Hooft JE, Ter Borg F, Siersema PD, Bemelman WA, Consten ECJ. Critical appraisal of oncological safety of stent as bridge to surgery in left-sided obstructing coloncancer; a systematic review and meta-analysis. Crit Rev Oncol Hematol 2018;13:66-75.

14. Cirocchi R, Farinella E, Trastulli S, Desiderio J, Listorti C, Boselli C, Parisi A, Noya G, Sagar J. Safety and efficacy of endoscopic colonic stenting as a bridge to surgery in the management of intestinal obstruction due to left colon and rectal cancer: a systematic review and meta-analysis. Surg Oncol 2013;22:14-21.
15. Tan CJ, Dasari BVM, Gardiner K. Systematic review and meta-analysis of randomized clinical trials of self expanding metallic stents as a bridge to surgery versus emergency surgery for malignant left sided large bowel obstruction. Br J Surg 2012;99:469-476.

16. Baron TH. Colonic stenting: a palliative measure only or a bridge to surgery? Endoscopy 2010;42:163-168.

17. Khot UP, Lang AW, Murali K, Parker MC. Systematic review of the efficacy and safety of colorectal stents. Br J Surg 2002;89:1096-1102.

18. Ng KC, Law WL, Lee YM, Choi HK, Seto CL, Ho JW. Self-expanding metallic stent as a bridge to surgery versus emergency resection for obstructing left-sided colorectal cancer: a case-matched study. J Gastrointest Surg 2006; 10:798-803

19. Tejero E, Mainar A, Ferna ndez L, Tobío R, De Gregorio MA. New procedure for the treatment of colorectal neoplastic obstruction. Dis Colon Rectum 1994;37:1158-1159.

20. Karadag A, Mentes BB, Uner A, Irkorucu O, Ayaz S, Ozkan S. Impact of stomatherapy on quality of life in patients with permanent colostomies or ileostomies. Int J Colorectal Dis 2003;18:234-238.

21. Martinez-Santos C, Lobato RF, Fradejas JM, Pinto I, Ortega-Deballón P, Moreno-Azcoita M. Self-expandable stent before elective surgery vs. emergency surgery for the treatment of malignant colorectal obstruction: comparison of primary anastomosis and morbidity rates. Dis Colon Rectum 2002:45:401-406

22. Repici A, Conio M, Caronna S, Angelis CD, Costa CD, Morino M, et al Early and late outcomes of patients with obstructing colorectal cancer treated by stenting and elective surgery: a comparison with emergency surgery and patients operated without obstructive symptoms. Gastrointest Endosc 2004;59:275.

23. Cheung HYS, Chung CC, Tsang WWC, Wong JCH, Yau KKK, Li MKW Endolaparoscopic approach vs. conventional open surgery in the treatment of obstructing left-sided colon cancer. A randomized controlled trial. Arch Surg 2009;144:1127-1132.

24. Guillou PJ, Quirke P, Thorpe H, Walker J, Jayne DG, Smith AM, Heath RM, Brown JM, MRC CLASICC trial group. Short-term endpoints of conventional versus laparoscopic assisted surgery in patients with colorectal cancer (MRC CLASSIC trial): multicentre, randomized controlled trial. Lancet 2005;365:1718-1726.

25. Liu L, Herrinton LJ, Hornbrook MC, Wendel CS, Grant M, Krouse RS Early and late complications among long-term colorectal cancer survivors with ostomy or anastomosis. Dis Colon Rectum 2010;53:200-212.

26. Quereshy FA, Poon JT, Law WL. Long term outcome of stenting as a bridge to surgery for acute left-sided malignant colonic obstruction. Colorectal Dis 2014;16:788-793.

27. Kavanagh DO, Nolan B, Judge C, Hyland JMP, Mulcahy HE, O'Connell PR, Winter DC, Doherty GA. A comparative study of short and medium term outcomes comparing emergent surgery and stenting as a bridge to surgery in patients with acute malignant colonic obstruction. Dis Colon Rectum 2013;56:433-440 